\title{
Venstreorienterede der blev højreorienterede uden at vide det
}

Torben Bech Dyrberg

Lektor på Institut for Samfund og Globalisering, RUC

Den form for venstreorientering, vi ser i dag, har indoptaget flere karakteristika, der plejede at kendetegne en reaktionær højrefløj. Det skyldes grundlæggende at den har vendt oplysningstraditionen ryggen og i stedet har udviklet en kulturalistisk profil, der kan spores tilbage til den tidlige efterkrigstid. Den form for venstreorientering, der udviklede sig her i opposition til socialdemokratisme og kommunisme, blev præget af tre par af strømninger. I slutningen af 1940'erne: modernitetskritik og konservativ antiimperialisme; den første postbølge i 1960/70'erne: kritik af autoriteter og overflodssamfund samt antiimperialisme og den anden postbølge i 1980/90'erne: relativisme og multikulturalisme.

\section{Det historiske sammenbrud i venstreorientering}

I 200 år havde venstreorientering været forbundet med universalisme og progressivitet, rationalitet og sekularisme, frihed og lighed, optimisme og emancipation samt materielle fremskridt. Men på to hundredeåret skete der en fundamental omvending af værdier ved at man overtog udsyn og holdninger, man altid havde stemplet som reaktionære.

Hvem er 'man' og hvad sker der? En umiddelbar indkredsning af, hvem der er venstreorienterede, er, at det er dem, der føler solidaritet med fattige og underkuede, bliver indignerede over social uretfærdighed og engagerer sig i social kritik (Berman 2010: 174; Lukes 2003: 616). Mere specifikt er den form for venstreorientering, jeg ser på, en, der udviklede sig i tiden efter 1945 i Vesteuropa og Nordamerika i opposition til de to hovedstrømninger i arbejderbevægelsen - socialdemokrater og kommuni- ster - og som i modsætning til disse ikke var rodfæstet i denne. Der er tale om yderst sammensatte strømninger, der markerer sig værdipolitisk, som over tid indvirker på hinanden og ændrer sig, og som er i opposition til systemet og højreorienterede. Aktørerne er typisk intellektuelle og politiske debattører, men det er blot toppen af isbjerget, for der er tale om måder at orientere sig på, der er rodfæstet i bredere segmenter i den politiske kultur.

$\mathrm{Vi}$ har at gøre med et fundamentalt skift $\mathrm{i}$ måden at orientere sig på i politik, der kan føres tilbage til den kulturalistiske dagsorden, der med stigende styrke har sat sig igennem siden slutningen af 1980 'erne. Som det fremgår af nedenstående skema, har aktuel værdipolitisk venstreorientering, som vi finder den ikke bare i en dansk sammenhæng fra kulturradikale til gammelsocialister men også i Vesteuropa og Nordamerika, overtaget flere af de værdier, der traditionelt kendetegnede en reaktionær højrefløj (Bronner 2004: 17; Furedi 2005: 66). Således hælder man i dag mod at:

- Promovere den opfattelse, at der er essentielle forskelle mellem mennesker, altså at man er rundet af og bundet til sin kultur

- Se modernitet eller senkapitalisme som noget, der fragmenterer fællesskaber og eroderer sammenhængskraft

- Forsvare over/underordning, for så vidt ulighed er naturlig $i$ betydningen kulturelt betinget

- Legitimere hegemoniske udlægninger af kollektive erfaringer, i det omfang de er bundet op på subkulturer

- Acceptere subkulturelle magteliter i Vesten og korrupte regimer og diktaturer i ikke-vestlige lande, hvis de er imod 'Imperiet'

Hvis man i få ord skal sammenfatte, hvad der kendetegner dette brud, må det være kulturalisme og defaitisme. De 'andres' kultur bliver set som en essentiel ramme, 
der bør beskyttes mod overgreb, fordi den udgør deres eksistensbetingelse. Der er flere årsager til, at kultur er kommet til at spille en så fremtrædende rolle: det har erstattet klasse, der tidligere fungerede som et samlende og politiserende begreb, og det har fået realpolitisk vægt pga. sammenbruddet i de kommunistiske regimer i Østeuropa og masseindvandringen til Vesteuropa, der på hver deres vis har skabt nye politiske konflikter, hvor kulturelle forskelle spiller ind.

Kulturalistisk og defaitistisk venstreorientering finder udtryk i mange sammenhænge, hvor de andres kultur og sammenhængskraft bliver brugt til at ytre modstand mod Vesten, systemet og forandring. Således kommer kulturrelativisme til udtryk i kritik af vestlig etnocentrisme, hvad angår videnskab og værdier; i en kritisk indstilling til vækst og udvikling; i en udpræget skepsis over for alt, der har at gøre med fornuft og sandhed (Bonnett 2010: 28-38; Malik 2008: 150-153, 195-203; Taverne 2005: kap. 8); i en reaktiv og risikoavers indstilling til forandring generelt og til alt, hvad der har at gøre med velfærdsstaten i særdeleshed (Furedi 2005: 9-12, 61-62, 64-65). Dertil kommer legitimering af indifference over for undertrykkelse hos de 'andre' (Bruce 2001: kap. 6); identifikation med radikale anti-vestlige islamister som de autentiske fortolkere af Islam samt mistillid til frihed, der går på valg- og ytringsfrihed, og en kritikløs hyldest til frihed forbundet med subkulturel forskellighed. Derudover er den generelle sindstilstand præget af skepticisme og defaitisme kombineret med gamle kendinge som selektiv indignation og moralske dobbeltstandarder samt en resignerende, men grandios alvidenhed og moralsk ophøjethed (Bruckner 2010: kap. 2; Furedi 2005: kap. 4). Man har altså stadig eneret på det gode menneskesyn, og højreorienterede er lige så onde, som de altid har været.

Tager man udgangspunkt i en traditionel højre/venstre-konstellation, ser man, at rollerne er, om ikke byttet om, så dog så udviskede, at det næppe giver mening at opretholde distinktionen. Det skyldes, dels at man har vendt den radikale oplysningstradition ryggen, og dels at man har adopteret en kulturalistisk dagsorden. Resultatet har været, at venstreorienterede har bevæget sig langt ind på højre banehalvdel.

Hvordan kan det være, at venstreorienterede og progressive støtter det, de altid har set som højreorienteret og reaktionært? Omdrejningspunktet for sammenbruddet i den værdipolitiske venstreorientering kan lokaliseres til to begivenheder, der i årene fremover skulle få en markant betydning for politisk orientering og identitetsdannelse langt ud over hvad der har at gøre med venstrefløjsidentitet. Det drejer sig om de kommunistiske regimers kollaps i Østeuropa i 1989 og Khomeinis fatwa mod den britiske forfatter Salman Rushdie samme år.

Men selv så markante begivenheder kan ikke sætte sig igennem med så stor styrke, medmindre jorden var gødet for dem - og det var den. For ikke bare var den udprægede venstrefløjsprofilering, der markerede de små to årtier fra starten af 1960'erne til slutningen af 1970'erne, ebbet ud i slutningen af 1980'erne; der var også nye strømninger

Oplysningstraditionens venstre vs. det klassiske højre og multikulturelle venstre

\begin{tabular}{|c|c|c|}
\hline Klassisk høire & Oplysningens venstre & multikulturel venstre \\
\hline $\begin{array}{l}\text { Kulturrelativisme: individer er rundet af og } \\
\text { bundet til deres kulturer, der danner rammen } \\
\text { for deres eksistensbetingelser }\end{array}$ & $\begin{array}{l}\text { Universalisme: frihed og lighed som en vision om at } \\
\text { individer ikke er bundet af kultur, klasse, mv., men } \\
\text { kan overskride disse }\end{array}$ & $\begin{array}{l}\text { Relativisme: universalistisk indstilling er erstattet af } \\
\text { kulturrelativisme, hvor individer er set som bundet } \\
\text { til deres kultur }\end{array}$ \\
\hline $\begin{array}{l}\text { Rodfæstning: præpolitiske relationer som } \\
\text { tradition og vaner (kultur) holder sammen på } \\
\text { og forsvarer status quo }\end{array}$ & $\begin{array}{l}\text { Frihedsrettigheder: frihed og lighed for alle uanset } \\
\text { social status, race, køn, etc., uanset hvor og hvem } \\
\text { der undertrykker }\end{array}$ & $\begin{array}{l}\text { Frihed er undertrykkelse: frihed bliver brugt til at } \\
\text { undertrykke 'den anden', vestlig etnocentrisme og } \\
\text { imperialisme }\end{array}$ \\
\hline $\begin{array}{l}\text { Reaktionær: essentielle forskelle mellem } \\
\text { klasser, nationer, racer og køn: „mennesket } \\
\text { eksisterer ikke“ }\end{array}$ & $\begin{array}{l}\text { Progressiv: fælles menneskelig betingelse på tværs } \\
\text { af kulturer: overvinde underordning og realisere én } \\
\text { menneskelighed }\end{array}$ & $\begin{array}{l}\text { Anerkendelse: ligestilling mellem kulturer, kritik af } \\
\text { vestlig etnocentrisme og af individualisme, fokus på } \\
\text { sammenhængskraft }\end{array}$ \\
\hline $\begin{array}{l}\text { Det givne: ulighed } \mathrm{i} \text { kraft af naturlige distink- } \\
\text { tioner og privileger relateret til nationalitet, } \\
\text { social status, køn, race, etc. }\end{array}$ & $\begin{array}{l}\text { Emancipation: handlinger der udfordrer det givne og } \\
\text { tilstræber frigørelse fra underordning og til kreativitet }\end{array}$ & $\begin{array}{l}\text { Kritik af fremskridt: reaktiv og risikoavers indstilling } \\
\text { til forandring, kritik af økonomisk vækst og udvikling }\end{array}$ \\
\hline $\begin{array}{l}\text { Erfaring og tradition: kultur som sammen- } \\
\text { holdsfaktor trumfer konstruktioner som ra- } \\
\text { tionalitet og fornuft, sandhed og rettigheder }\end{array}$ & $\begin{array}{l}\text { Fornuft og sandhed: viljen til et villet fællesskab } \\
\text { trumfer det umiddelbare og traditionelle, politik som } \\
\text { sammenholdsfaktor }\end{array}$ & $\begin{array}{l}\text { Rationalitet og fornuft som dominans: magt og } \\
\text { viden er to sider af samme sag og bestemt af kon- } \\
\text { tekst og strategi }\end{array}$ \\
\hline $\begin{array}{l}\text { Establishment: forsvar for det system mag- } \\
\text { teliter er rundet af i det omfang de ikke } \\
\text { bryder den kulturelle ramme }\end{array}$ & $\begin{array}{l}\text { Opposition: kritik af naturlige hierarkier og dem, der } \\
\text { forsvarer dem, samt forsvar for dem, der er ude } \\
\text { og nede }\end{array}$ & $\begin{array}{l}\text { Modløshed og defaitisme: undertrykkelse skal kun } \\
\text { kritiseres, hvis det er de 'rigtige', der udøver den, } \\
\text { ellers ikke }\end{array}$ \\
\hline
\end{tabular}


som multikulturel identitetspolitik med dertil hørende politiske korrekthed og sarthed over for at blive stødt, der begyndte at markere sig i starten af årtiet, og som i de efterfølgende år kom til at præge venstreorientering. ${ }^{1}$ Dertil kommer et sæt af mere langsigtede forhold, der er emnet for denne artikel. Det drejer sig om, at den form for venstreorientering, jeg fokuserer på her, og som begyndte at tage form i den tidlige efterkrigstid, har lagt sporene ud for den måde at orientere sig på, der præger venstreorienterede i dag. Hensigten er at skitsere, hvordan denne venstreorientering har udviklet sig i disse 7 årtier, og idéen er at indkredse disse spor mhp. at finde ud af, hvordan de udvikler sig, glider over i og præger hinanden i takt med historiske forandringer.

Jeg vil hæfte mig ved tre sæt af nedslagspunkter, der udtrykker forskellige former for kritik. De markerer en værdipolitisk opposition til systemet og/eller kulturen, hvor selve det at være i opposition identificerer én som venstreorienteret. Jeg vil især se på første og tredje fase. Det drejer sig om sidste halvdel af 1940'erne, hvor man ser begyndelsen til en modernitets- og universalismekritik; første postbølge i 1960/70'erne, hvor det nye venstre er forankret i livsstils- og imperialismekritik, og anden postbølge i 1980/90'erne præget af relativisme og multikulturalisme. I forlængelse heraf vil jeg skitsere, hvordan disse ændringer paradoksalt nok både afliver venstrefløjens værdipolitiske grundlag og motiverer den gennem nye ven/fjende konstellationer.

\section{Kritik 1-2: den tidlige efterkrigstid}

I den tidlige efterkrigstid kan man se starten på to typer kritikker, der i de efterfølgende årtier satte deres præg på venstreorientering. Det drejer sig for det første om, at kritik bliver abstrakt og filosofisk, og for det andet at kritik bliver kulturrelativistisk. Disse kritikker handler om, at kapitalismens destruktive produktivitet glider over $i$ en kritik af modernitetens fragmentering af sociale relationer og fællesskaber; og at kritikken af imperialistisk undertrykkelse udarter sig til en kritik af vestlig etnocentrisme og magtbrynde, hvis modstykke er undertrykte folk i den tredje verden.

\section{1.}

Den første kritik drejer sig om Kritisk Teoris sammentænkning af Marx, Freud, Nietzsche og Weber i noget, der mere ligner kritik af modernitet end af kapitalisme (Horkheimer 2007: 36, 39). Denne kritik, der især er forbundet med Adorno og Horkheimers „Oplysningens dialektik“, har ikke nogen umiddelbar effekt, men får det senere igennem Marcuses indflydelse på radikaliseringen af ungdomskulturen, hvor især studerende fra starten af 1960'erne spillede en central rolle (Bonnett 2010: 32-33).
Kritisk Teoris nyskabelse bestod i, at det, marxismen så som den basale modsætning under kapitalismen mellem kapital og arbejde, blev afløst af en abstrakt kritik af instrumentel fornuft. Hvor kapital/arbejde blev modsvaret af aktører i den virkelige verden (borgerskab/arbejderklasse), var den instrumentelle fornuft ikke bundet op på aktører. Eller rettere, alle var indfanget af denne generelle bevidsthedstilstand, i og med den kredsede om at få kontrol med andre og med naturen. Fordi man ikke kunne undslippe den, udgjorde den en slags skæbne. Det har stor betydning for en venstreorienteret politisk forestillingshorisont, dels fordi modstand i realiteten bliver umulig, og dels fordi denne fatalisme får visse ligheder med det, der plejede at kendetegne reaktionære forestillinger.

I forlængelse heraf kan man hæfte sig ved, at kritik af denne omsiggribende beherskelsestrang bliver defaitistisk og apokalyptisk. Man havner i det handlingslammende paradoks, at modstand er nødvendig og umulig, da den i udgangspunktet bliver indfanget af det, den sætter sig op imod (Bérubé 2009: 84-86, 246-247). Følgerne heraf viser sig i den form for eksistentiel venstreorienteret identitetspolitik, der præger første postbølge i 1960’erne, men det kaster også længere skygger frem. Der er tre forhold, der er vigtige, og som kredser om, at ven/fjende-forhold er afgørende identitetsskabende faktorer.

For det første indebærer den abstrakte og defaitistiske kritik et historisk brud i venstreorientering. Denne havde altid været intimt forbundet med oplysningstraditionens fremtidsorientering og universalisme, der igen havde været udtrykt i fornuft, videnskabelig sandhed, autonomi og transparens (Bronner 2004: 19, 23, 29; Lukes 2003: 611; Malik 2008: 5). Hermed stod progressive over for reaktionæres insisteren på erfaring og intuition samt på givne forhold som social og kønslig stratifikation. Sammenkædningen af venstre-fremme, der står i modsætning til højre-tilbage, bliver obstrueret af dislokationen i førstnævnte. Det er vigtigt for at forstå den politiske og intellektuelle desorientering, der fremover kom til at præge venstreorientering. ${ }^{2}$

For det andet udmønter den abstrakte filosofiske kritik sig i en form for magt/modmagt-logik, hvor det ikke handler om at opnå dette eller hint, men om at iscenesætte en eksistentiel bekræftelse af sin subversive og derfor autentiske subjektivitet. Her ser vi spirerne til to forhold, der kom til at spille en væsentlig rolle for venstreorientering i de følgende årtier. For det første en kulturalistisk trend, hvor kulturers egenart dyrkes og stilles op imod vestlig imperialisme og borgerlig kultur. Kognitiv, politisk og retlig fragmentering former tankegodset i den senere multikulturalisme (Bruce 2001: kap. 6; Eriksen og Stjernfelt 2008: 131-145). For det andet ser vi en vitalistisk og de facto anarkisk og individualistisk form for 
modstand, der satte sig igennem med fuld styrke i det nye venstre i 1960'erne, der af samme grund kan ses som mere libertariansk og middelklasse end socialistisk og arbejderklasse. ${ }^{3}$ Med til dette billede hører også, at modstand er mest autentisk, når den har mindst gennemslagskraft. Med andre ord, jo flere man er oppe imod og jo mere marginal man er, desto mere sandt er det, man siger. ${ }^{4}$

For det tredje er den abstrakte kritiks politiske modstykke fiktionen om og begæret efter 'den anden' som den, der repræsenterer negationen af både ens egen livsform og af Systemet og som derfor inkarnerer en fuldbyrdet identitet. Afstanden til det attråede og dennes helhed er centrale virkemidler i denne ideologiske konstruktion, der kredser om skyld over at være privilegeret og romantisering/infantilisering af andethed. Rollen som den anden kan, alt efter temperament og tidspunkt, udfyldes af den utilpassede hippie, det revolutionære orakel, nationale regimer og befrielsesbevægelser i det kapitalistiske systems periferi samt ikke-integrerede subkulturer i de kapitalistiske centre. Hermed indskriver den anden sig i den identitetsstimulerende ven/fjende-konstellation, hvor fjenden ret beset er én selv! Dette patologiske aspekt af den abstrakte kritik leder over i den kulturrelativistiske kritik, der er det andet hovedspor i den tidlige efterkrigstids nye kritikform.

\section{2.}

Den anden kritik udvikledes af antropologer i USA, der uden held bestræbte sig på at relativere de universalistiske ambitioner i FN's menneskerettighedscharter i 1948 (Eriksen og Stjernfelt 2008: 145-151; Malik 2008: 166169). Hvor den første trend er udpræget kritisk og skeptisk over for rationalitet, er den sidste en hybrid identitet af konserverende kulturrelativistisk antiimperialisme. Men hvor antropologlobbyisterne ikke formåede at relativere FN's menneskerettighedsdeklaration, lykkedes det dem til gengæld året efter, med oprettelsen af UNESCO, at få kultur centralt placeret. I lyset af holocaust havde videnskabelig racisme ingen legitimitet længere, hvilket vil sige, at genetiske forskelle ikke kunne forklare forskelle mellem befolkningsgrupper (Eriksen og Stjernfelt 2008: 175-178). Det kunne kultur derimod. Hermed fik det en funktionel lighed med racisme, fordi man med kultur kunne forklare det samme, som man hidtil havde villet forklare med racisme, altså grunde til forskelle mellem befolkningsgrupper. Således var 'UNESCO-mennesket' biologisk set ét, men kulturelt set en pluralitet, og denne mangfoldighed kunne i modsætning til racismens over/ underordningslogik ikke rangordnes (Malik 2008: 158159).

Skiftet fra race til kultur indebar et skifte fra vertikal til horisontal segmentering, der i udgangspunktet var formet af både oplysningsidealet om universel lighed og den romantiske modreaktions vægtning af kulturel rodfæstning. Det lagde grunden til en kritik af oplysningstraditionens universalisme og rationalisme, der blev set som et udtryk for Vestens etnocentrisme, arrogance og imperialisme. Således bliver denne traditions syn på lighed som tæt forbundet med fremskridt, der overvinder undertrykkelse og uvidenhed og som derigennem frisætter menneskers kreativitet og muliggør en realisering af en fælles menneskelighed, erstattet af et andet syn på lighed, der går på, at mennesker er lige, fordi de kulturer, der udgør deres eksistensbetingelser, eller rettere skaber dem, ikke kan sættes ind i et globalt hierarki (Malik 2008: 157-159, 162-164). Det er denne kulturalistiske forståelse af lighed, der er omdrejningspunkt for, at de, der ser sig selv som progressive og lighedsorienterede, i dag er skeptiske, desillusionerede eller fjendtlige over for fremskridt og individualitet og ikke bliver indigneret af undertrykkelse, hvis det kan bortforklares som kulturel forskellighed. Det hører med til dette syn på lighed, at kulturer basalt set er lukkede, dvs. de udgør en helhed, der definerer relationerne mellem deres dele (individer). Heraf følger også, at det ikke giver mening at beskytte individer mod det samfund, de er en del af, og at det er meningsløst at tale om frihed på tværs af kulturer. Begge antagelser er essentielle elementer af det, der små fire årtier senere blev kendt som multikulturalisme og som har lighedspunkter med reaktionær højreorientering.

\section{Kritik 3-4: den første postbølge, det nye venstre}

Det næste nedslagspunkt er den første postbølge, der prægede 1960 'erne og strakte sig ind i 1970'erne. Baggrunden var efterkrigstidens uhørt store produktivitetsudvikling og velstandsstigning, der ekspanderede velfærdsstaten og medførte et uddannelsesboom. Nye sociale lag, nye medier, nye horisonter og udfordringer var nogle af de forhold, der var med til at skabe en ungdomskultur af globale dimensioner (Sassoon 2010: kap. 14). De politiske og sociale udtryk for denne kultur er i flere henseender paradoksale. Her skal blot nævnes tre: at den er betinget af et kapitalistisk overflodssamfund, samtidig med at den retter al sin kritik herimod; at den propaganderer en total revolution, der omfatter alle livets forhold, samtidig med at den er udsprunget af og bundet til middelklasseværdier; og at kvindebevægelsens kamp for rettigheder, ligestilling og deltagelse $\mathrm{i}$ det offentlige liv gik hånd $\mathrm{i}$ hånd med kapitalismens 'kolonisering' af dagliglivet (Lindsey 2007: 147, 192-193, 217-218, 234-235).

Der er dog især to typer kritikker, det er værd at se nærmere på. Den ene retter sig mod overflodssamfundet med sin materialistiske og inautentiske livsstil og hierarkiske og stivnede autoriteter; den anden fokuserer 
på antiimperialistiske befrielseskrige i Afrika, Asien og Latinamerika.

3.

Den første kritik, der i mangel af bedre kan kaldes naturlig, kommer i to nært forbundne former: en kritik af stivnede livsformer, hierarkiske og autoritære institutioner samt overflodssamfundets „endimensionale“ fokus på materialisme og forbrugerisme; og en kritik af ødelæggelse af miljøet grundet økonomisk vækst og som en søgning mod det naturlige og holistiske frem for det fremmedgjorte og fragmenterede. Hvor ikonet for den første kritik var Marcuse, var det for den anden Rachel Carson, hvis Silent Spring fra 1962 er den måske til dato bedst sælgende økokatastrofe fortælling (Taverne 2005: 27-33). Disse kritikker trækker i varierende grad på den foregående periodes to kritikker af modernitetens rationalisme, instrumentalisme og individualisme, ligesom de begge er forbundet med nostalgi og romantisering af det emotionelle, naturlige og oprindelige (Lindsey 2007: 198-199). Symptomatisk for denne type kritik hævder Marcuse, at "Concentration camps, mass exterminations, world wars and atom bombs are no 'relapse into barbarism' but the unrepressed implementation of the achievements of modern science, technology and domination" (citeret i Malik 2008: 156). Kapitalismekritikken blev også farvet af denne kritik af rationalitet. Hvor venstreorienterede tidligere havde kritiseret kapitalismen for at være ineffektiv pga. tilbagevendende økonomiske kriser, der forarmede store befolkningsgrupper, og umenneskelig pga. nedslidning, umyndiggørelse og fremmedgørelse, blev kritikken nu vendt på hovedet. Nu gik den på, at kapitalisme var for effektiv, at overflodssamfundets materielle velstand avlede konformitet og åndelig fattigdom, og at det med Marcuses ord excellerede i „repressiv tolerance“, der indoptog og dulmede modstand.

4.

Den anden kritik, antiimperialismen, har et andet forankringspunkt. Med efterkrigstidens økonomiske boom mistede man håbet om, at arbejderklassen i Vesten ville være i stand til at gennemføre en socialistisk revolution, hvilket gik hånd $\mathrm{i}$ hånd med skepsis over for socialdemokratiske og kommunistiske partier. Således rettede radikaliseringen af ungdommen i 1960'erne sig ikke mod det, der traditionelt var venstrefløjens fokus, nemlig arbejderklassen og social ulighed. I stedet blev det politiske tyngdepunkt forskudt til den tredje verdens antiimperialistiske befrielseskrige (Markovits 2005). Dette var den konkrete anledning, men grundlaget for at re-orientere venstreorientering var tilvejebragt dels af en skepsis over for arbejderklassen, der blev set som opslugt af den bor- gerlige materialistiske kultur, og dels af den kommunitære og antiimperialistiske kulturalisme, der voksede op i efterkrigstiden.

Især Vietnamkrigen var central for den politiske identitetsdannelse, hvor modstanden mod USA skulle trække lange spor, der undertiden kunne være svær at skelne fra anti-amerikanisme. Generelt var det afgørende ikke, hvorvidt de nye regimer i Afrika, Mellemøsten og Asien var socialistiske eller på vej til at blive det. De udviklede sig alle til at blive autoritære og korrupte, men det var underordnet af to årsager. For det første fordi de som fjendens fjende var imod det imperialistiske center og dermed pr. definition indtog en progressiv rolle. Det gjaldt især i den tidlige periode, hvor regimer i Afrika og Mellemøsten besmykkede sig med demokratisk og socialistisk retorik. For det andet fordi den kulturrelativistiske drejning legitimerede indifference, hvorfor man ikke behøvede at kere sig om 'indre anliggender'. Her var man i øvrigt i god træning, da man altid havde været tavs om kommunistiske regimers forbrydelser og folkemord.

\section{Kritik 5-6: den anden postbølge, det multikultu- relle venstre}

Den anden postbølge opstod i slutningen af 1970'erne, slog igennem i starten af 1980'erne og ebbede ud i 1990 'erne. Centrale temaer var i høj grad forskel frem for identitet, kontekst frem for universalisme og magt frem for rationalitet. Den postbølge, der udviklede sig i multikulturalistisk retning, startede i 1980'erne og havde længere levetid, fordi den fik politisk fodfæste i forhold til diverse subkulturer og satte et vist præg på lovgivningen, hvilket igen hænger sammen med masseindvandringen til Vesteuropa. Frem for alt fik den momentum med den kulturalistiske drejning, der satte sig igennem fra og med slutningen af 1980'erne.

5.

Det er et kendetegn ved anden postbølge, at man betvivlede alt det, man tidligere havde troet på, men som nu blev set som en ideologisk illusion. Hvor ideologi tidligere havde været set som noget, der fordrejede sandheden og derigennem var med til at fastholde borgerskabets klassedominans ved at generere falsk bevidsthed og fremmedgørelse, var der nu ikke længere nogen sandhed at fordreje og intet væsen under overfladen. Og nok så væsentligt: den forbindelse, marxister altid havde taget for given mellem deres udlægning af sandhed og emancipatorisk politik, faldt fra hinanden. Hvorvidt emancipation selv var et blændværk, var omdiskuteret, men i hvert fald kan man sige, at den vished om at have ret, som det krævede at kæmpe for den, ikke længere var til stede. For der var intet arkimedisk punkt, hvorfra man kunne overskue det 
hele, hvorfor universalisme var en etnocentrisk illusion. Rationalitet og fornuft var blot magtstrategier på linje med alle andre, og det samme gjaldt udvikling og fremskridt (Taverne 2005: 10-14, 23-25, kap. 8). Så flere af de temaer, der var blevet rejst af det nye venstre $\mathrm{i}$ årtierne før, blev videreført i anden postbølge. Men i modsætning til tidligere blev alt nu kontekstbestemt og ikke mindst blev alt usikkert.

Hermed lå disse strømninger på kanten af det at være venstreorienteret, fordi de relativerede alt det, der havde været omdrejningspunkt for venstreorientering gennem 200 år. Heri ligger der et paradoks, nemlig at de forskellige posttrends så sig selv i termer af re-politisering ved at påpege, at der ikke var nogen nødvendighed eller logik, der satte sig igennem. Men aktørerne, der skulle kæmpe, havde i al væsentlighed mistet motivationen. Poststrømningerne problematiserede logikken i den abstrakte kritik og excellerede i dekonstruktive afsløringer af det, man postulerede folk tog for givet. Men andet havde man ikke at byde på, bl.a. fordi man hverken kunne eller ville reartikulere den radikalitet, der lå i oplysningstraditionen. Således fortsatte man det filosofiske selvsving, der yderligere isolerede venstreorienterede fra den politiske virkelighed.

\section{6.}

Hvor den anden postbølge i høj grad var et universitetsfænomen, fik dens multikulturalistiske fætter mere realpolitisk relevans, fordi den var forbundet med en identitetspolitisk bølge, der især profilerede religiøst og etnisk tilhørsforhold samt identitetspolitik relateret til $\mathrm{k} ø$ og seksualitet. Det multikulturelle venstre udviklede sig op gennem 1980 'erne, hvor politisk korrekthed tog form af kritik af racisme og sexisme. Sidstnævnte blev dog fortrængt af førstnævnte (Berman 2010: 210-212; Bruce 2001: kap. 5; Sørensen m.fl. 108-113), hvilket må ses i lyset af kulturalismens fremmarch, der hænger sammen med tre forhold. Med Murens fald krakelerede den skrantende kapitalisme/socialisme-modsætning, hvilket udløste konflikter og krige af etnisk, religiøst og nationalt tilsnit. Med fatwaen mod Rushdie satte en totalitær teokratisk tredjeverdensstat Vesten med dens frihedsrettigheder under pres, hvilket var en medvirkende årsag til at fremme en radikal og selvbevidst islamistisk identitetspolitik (Malik 2009: 18, 126). ${ }^{5}$ Endelig er kulturalismens fremmarch forbundet med masseindvandringen fra især muslimske kulturer, som venstrefløjen har haft interesse i at promovere, da det har fungeret som en slags modkultur til Vesten og Systemet.

Denne situation var fremmedartet ikke for bare den gamle venstrefløj, der var rodfæstet i arbejderbevægelsen. Men det nye venstres løsrivelse herfra havde givet dens værdibaserede politiske orientering en egendynamik, der havde ført den stadig længere væk fra 'almindelige mennesker'. Hvor venstreorienteret kulturalistisk identitetspolitik førte i retning af multikulturalisme, førte højrefløjspendanten i retning af en xenofobisk og populistisk mono-/national kulturalisme, der i årene efter fatwaen oprustede mod islamisme og indvandring fra muslimske lande. Som følge heraf er højre/venstre-orientering blevet udvandet og konfliktlinjer bliver trukket anderledes (Dyrberg 2008). Det er kommet til udtryk i konflikterne mellem nationalistisk og subkulturel identitetspolitik, der har forskubbet den politiske dagsorden i en kommunitær retning. Hvis venstreorientering problematiserede sig selv med anden postbølge i og med kritikken af universalisme, fremskridt, individualisme og rationalitet, er den blevet yderligere forkrøblet med multikulturalismen, i og med den har overtaget klassiske reaktionære positioner.

For at forstå venstrefløjens identitetspolitiske udvikling i de sidste par årtier vil det være nærliggende at se på reaktionerne på fatwaen mod Rushdie 14/2 1989. Man kunne have troet, at venstreorienterede ville have støttet Rushdie. Han var selv venstreorienteret og havde en markant antiracistisk profil; det segment, han var en del af (kunstinstitutionen), var mere liberalt og venstreorienteret end autoritært og højreorienteret, og venstreorienterede kunne besmykke sig med at kæmpe for de svages ytringsfrihed mod en overmagt. Dertil kom, at der var flere konservative journalister, forfattere og politikere i UK og USA, der ikke lagde skjul på deres foragt for Rushdie (Cohen 2012: 33-42; Malik 2009: 32-35). Men disse argumenter var langtfra tunge nok til at have nogen virkning. Der er tre forhold, der medførte, at venstrefløjen ikke kom til at spille nogen rolle. De to første danner en baggrund for tavsheden, der vedrører konsekvenserne af dens abstrakte kritikform og begæret efter den anden, hvorimod den sidste var udslagsgivende og handler om frygt.

For det første havde man i de forløbne fire årtier forpuppet sig i abstrakte former for kritik, der havde meget lidt relevans, når det gjaldt om at forholde sig til den politiske virkelighed. Allehånde kritikformer forbundet med det nye venstre og dens post-aftagere havde fordybet sig i kapitalismen og overflodssamfundets fremmedg $\varnothing$ relse, i modernitetens instrumentelle fornuft, der var lig dominans og eliminerede opposition. Man havde forsøgt at forklare kapitalismens overlevelse mod alle odds ved hjælp af dens endogent genererede falske bevidsthed og den herskende klasse og kulturindustriens ideologiske manipulation, alt sammen noget, der slørede realiteterne og sløvede de udbyttede massers bevidsthed. Dertil kom et andet forhold, nemlig at den abstrakte kritiks apokalyptiske karakter havde udmanøvreret konkrete politiske 
analyser. I stedet havde man hengivet sig til et Orwellsk 1984-univers, hvor alle distinktioner, der betyder noget i den virkelige verden, var imploderet og stiliseret i teoretiske deduktioner. Her kunne man udlede totalitarisme og manipulation fra liberalisme og oplysningstradition, her generede det progressive og moderne det regressive og barbariske, og her slog demokrati over i fascisme (Bronner: 109-110). Sammenfattende om disse to forhold kan man sige, at det næppe kan undre, at en venstrefløj, der var rundet af denne form for kritik, ikke var i stand til at påtage sig et ansvar og reelt gøre sig gældende over for dødstrusler mod kunstneres ytringsfrihed, som den havde taget for givet, men aldrig ville forsvare.

For det andet havde man i de forgangne fire årtier gjort „den anden“ til ikon for det, man ikke selv havde, nemlig kultur, der var rodfæstet, længe før „vi“ (Vesten, moderniteten, imperialismen) koloniserede dem og besmittede deres integritet og sammenhængskraft. ${ }^{6}$ Det er dette romantiserede billede af den anden - og konkret af hvad regimer i den tredje verden, der er kritiske over for Vesten, siger og gør - der tjente som den vesteuropæiske og nordamerikanske venstrefløjs holdepunkt for sin egen identitetspolitiske profilering. Kultur er på betryggende afstand, det er noget, de andre har, og dermed accepterede man stiltiende at tale ud fra den privilegerede universelle position, man ellers gjorde en dyd af at tale op imod. Det er i den forbindelse værd at tænke på, at de højrepartier, der udviklede sig i denne periode - der kombinerede elementer af nationalisme, racisme og populisme - i mangt og meget kan ses som et spejlbillede på denne form for venstreorientering. Frem for alt fordi man tog sin egen kultur på sig i stedet for at benægte den. Så for at vende tilbage til Rushdie og dermed til, hvorfor venstreorienterede ikke følte sig kaldet til at gøre noget: for det første har man en venstrefløj, der har immuniseret den andens kultur fra vestlig kritik, og som ser denne kultur som en enhed, hvorfor man ikke ynder at tale om, at magteliter undertrykker deres befolkninger. Så disse regimer kan ikke være andet end et autentisk udtryk for kulturen, og dermed forstummer kritik. For det andet havde denne venstrefløj altid været skeptisk over for liberalt demokrati med dets frihedsrettigheder, selvom man havde lukreret på det. Denne skepsis skulle i årene fremover blive vendt til egentligt had mod ytringsfrihed, der blev set som de stærkes magt over for de svage. ${ }^{7}$ I forlængelse heraf kan man for det tredje nævne, at venstreorienteredes trang til at pålægge sig selv og andre censur for ikke at såre de svages følelser indebar dels en infantilisering af dem, man talte på vegne af, og dels en intimisering af offentlighed, hvor følelserne hos autoriserede ofre fik tilkendt en vetoret for, hvad man måtte sige. Her har man endegyldigt forladt en højre/venstre-logik, der næres af opposition, til fordel for en hierarkisk logik, hvor retten til at ytre sig er bestemt af, hvem der er stærke og hvem der er svage, og hvor i stærk/svag-hierarkiet man befinder sig.

Endelig for det tredje var der et nyt fænomen, som fatwaen aktualiserede og som trængte sig på med alarmerende styrke, nemlig frygt. Hvor de to andre forhold dannede baggrunden for venstreorienteredes tavshed, blev frygt et virkningsfuldt magtmiddel til at censurere litteratur, teaterstykker, udstillinger, film, satiretegninger, etc. og til at få kunstnere til at udøve selvcensur, inden de begav sig ud i noget, der kunne tages til indtægt for en kritik af Islam (Berman 2010: 296-299). Med fatwaen, hvor en statsleder udstedte en dødstrussel på en privatperson i et andet land, indtraf der en ny form for terrorisering af politisk omgangsform og ytringsfrihed. Hvor det tidligere havde været sådan, at dissidenter fra kommunistiske regimer, der var kommet til Vesten, alt i alt kunne leve i fred fra deres tidligere bødler, var situationen nu, at bødlerne kunne dukke op i ens hjem og kunne true dem, der brugte deres ytringsfrihed, og deres familier. Der er utallige eksempler på den slags trusler og intimidering, hvor vold, mord og ildspåsættelse var blandt de midler, islamistiske bøller brugte til at kue dem, der ikke rettede ind (Cohen 2012: 43-53, 87-97). Det var ikke længere nødvendigt, at en ayatollah langt væk skulle autorisere dødsdommene og chikanerierne. Alene mistanken om, at noget kunne støde muslimers religiøse sensibilitet, kunne være nok til at sige fra (Cohen 2012: 43-53).

Det, der skete $\mathrm{i}$ årene efter udstedelsen af fatwaen, var, at den blev indlejret i ikke bare kunstinstitutionen, men også i den politiske kultur. Det indebar for det første en udbredt grad af hykleri, hvor selvcensur og politisk korrekthed blev lanceret i navn af åbenhed og tolerance, respekt og anerkendelse. En censur, der er så meget desto mere effektiv, fordi de, den rammer, ikke vil anerkende dens eksistens. For det andet udviklede der sig et Stockholmsyndrom i masseformat, hvor venstreorienterede kom til at se reaktionære, autoritære, sexistiske religiøse fanatikere som udtrykkende ægte islamisk kultur, hvilket lå i det kulturalistiske kort, hvor man ikke har øje for 'interne' konflikter i kulturer. Som Cohen (2012: 51) udtrykker det: "They treated Muslims as a homogeneous bloc, and allowed the reactionaries to set the cultural agenda." I forlængelse af dette kan man for det tredje nævne, at venstreorienterede med dette træk svækkede muligheden for at komme i kontakt med det store flertal af flygtninge og indvandrere fra Mellemøsten, der ikke brød sig om radikale islamister eller måske ligefrem var flygtet fra dem. Det ser ud til, at man her begår den samme fejltagelse, som man gjorde under den kolde krig, hvor man vendte ryggen til kritikere af kommunismen for ikke at komme til at fremstå som imperialismens støtter 
(Cohen 2012: 31). En lignende logik synes at gøre sig gældende her, dog med den forskel, at det nu ikke foregår bag et jerntæppe, men blandt ens medborgere.

Sammenfattende gælder det, at venstrefløjens forpuppede univers og hang til kulturalisme har blokeret for, at den kunne tage den udfordring op, der er opstået i et multikulturelt samfund med nye politiske grænsedragninger. Vi har også at gøre med en venstrefløj, der groft sagt aldrig har kæmpet for andet end med sin identitetspolitiske selviscenesættelse under betingelser, hvor man ikke havde noget at frygte. Man har omkostningsfrit kunnet levere en indædt kritik af Kristendom, regering og herskende klasser uden at frygte for sit liv. Men når det gjaldt kampen for ytringsfrihed, ville venstreorienterede løbe en risiko for at blive voldet af religiøse fascistiske bøller. Det var man ikke parat til. Så lad mig afslutte med Cohens (2012: 45) karakteristik af dette venstrefløjssegment:

"a campaign for free speech would involve them running a slight risk of becoming the target of violence themselves. They soon found high-minded reasons to avoid it, and redefined their failure to take on militant religion as a virtuous act. Their preferred tactic was to extend arguments against racism to cover criticism of religion."

\section{Paradokser for det multikulturelle venstre}

Det, vi ser med den anden postbølge og de kritikformer, der knytter sig hertil, er, at de har tenderet mod at erodere de måder at orientere sig på, der har kendetegnet oplysningstraditionens venstreorientering. Denne indholdstømning er sket, samtidigt med at radikal islamisme i højere og højere grad har været i stand til at præge den politiske dagsorden og sætte sig på, hvad antiimperialisme og antisystem er. Det er fx kommet til udtryk i OIC, der portrætterer muslimer som ofre for vestlig imperialisme, og som i over et årti har forsøgt at kriminalisere religionskritik i FN-regi (Eriksen og Stjernfelt 2008: 182-183). Flere venstrefløjskritikere af Jyllandspostens Muhammad-tegninger formulerede sig på linje hermed (Dyrberg 2012: 88-94). Så kombinationen af

- at ens gamle positioner blev miskrediterede, altså at socialisme udartede sig fra emancipation til noget, der mere lignede et mareridt,

- at man har indoptaget en kulturalistisk og konservativ dagsorden og dermed har udvandet meget af det, der var forbundet med universalisme, progressivitet og rationalitet, samt

- at islamister har gjort fælles sag med en multikulturalistisk sindet venstrefløj og dermed i et vist omfang kan udfylde dette tomrum, fordi det retter sig mod de samme hadeobjekter og har et sprog at gøre det i, har ledt til det paradoks, at multikulturalisme har opfyldt et venstreorienteret identitetspolitisk begær efter at være i opposition, samtidig med at det også har bidraget til at undergrave, hvad det vil sige at være venstreorienteret. Ven/fjende-relationen, der dyrkes i værdi- og identitetspolitikken, er altafgørende for den form for venstreorientering, jeg har beskæftiget mig med her, hvor ledetråden er at være imod Systemet og Vesten, uanset om det så betyder, at man gør vold på det, der plejede at være ens værdier (Berman 2010: 176-181; Bruce 2001: 13). Det væsentlige er at være i opposition, og det er det, ens udsyn rettes ind efter. Prisen for at bevare denne modstandsidentitet har været, at evnen til principiel stillingtagen og dermed også troværdighed er blevet svækket.

Det er i det lys, man kan se venstrefløjens hældning mod multikulturalisme, for den har virket identitetsunderstøttende for venstrefløjen som en politisk strømning, samtidig med at den i værdipolitisk henseende har gjort venstreorienterede højreorienterede:

- I og med poststrømningernes insisteren på at alt var kontekstbestemt, var det blot et skridt til at sige, at det var bestemt af kultur, da det især var den kontekst, der bød sig til efter den kolde krig, hvor en identitetspolitisk dagsorden slog igennem. Dette har understøttet kulturrelativistiske argumenter, der har til opgave at sikre kulturers sammenhængskraft, hvilket bl.a. indebærer at fastholde hierarkiske magtforhold. Altså en klassisk reaktionær dagsorden, der nu går for at være progressiv (Malik 2009: xix-xx).

- Man kunne blot sætte 'den andens kultur' foran eksempelvis racistisk og sexistisk undertrykkelse, så ville den blive usynlig for en politisk korrekt venstrefløj, fordi det ville blive parkeret bag en forglemmelsens Berlinmur. Det har ledt til en udbredt brug af dobbeltstandarder, hvilket også er klassisk reaktionært og imperialt tankegods.

- Som både fatwaen mod Rushdie og karikaturkrisen understreger, gælder det, at hvis vores frihedsrettigheder krænker den anden, er det vores pligt at undsige dem, og hvis de begår vold mod os, er det, fordi vi har stødt dem, hvorfor vi skal censurere os selv stadig mere. Denne tankegang er blevet hjulpet på vej af udbredelsen af nye trends, der går på anerkendelse vs. krænkelse. Argumentationsformen er én, der ligner klassisk højrefløjspopulisme med at tale på det tavse flertals vegne, nu blot med minoriteter i stedet.

- I og med kapitalismekritikken mistede momentum og mere og mere tog form af en modernitetskritik, og imperialismekritikken mere og mere blev en kritik af Vesten med USA og Israel i spidsen, har man indtaget en position, der ofte har været sammenfaldende med den radikale islamismes kritik af Vesten med dens imperialisme, korsridderfelttog og zionisme. Denne form for kritik, der er tæt forbundet med antiamerika- 
nisme og antisemitisme, er ikke ny, men kendetegner den inspiration, fascisme har haft for udformningen af radikal islamisme i det 20. århundrede (Bruckner 2010: 74-80; Lévy 2008: 127).

- Endelig kan man hæfte sig ved, at ligesom venstrefløjen i sin tid købte det, der var på den antiimperialistiske hylde, uanset om de progressive udviklede

\section{Litteratur}

Berman, Paul (2010). The Flight of the Intellectuals, New York: Melville House.

Bérubés, Michael (2009). The Left at War, New York \& London: The New York University Press.

Bonnett, Alistair (2010). Left in the Past: Radicalism and the Politics of Nostalgia, New York og London: Continuum.

Bronner, Stephen Eric (2004). Reclaiming the Enlightenment, New York: Columbia University Press

Bruckner, Pascal (2010). The Tyranny of Guilt: An Essay on Western Masochism, Princeton \& Oxford: Princeton University Press.

Cohen, Nick (2012). You Can't Read This Book, London: Fourth Estate.

Dyrberg, Torben Bech (2008). 'Identitetspolitisk offerideolgi og hykleri - om venstreorientering i dag', Kritik 188, p. 3-18.

Dyrberg, Torben Bech (2012). 'Den tavse venstrefløjspolitik: At være og at gøre tavs', i Tidsskriftet Antropologi, Nr. 65: 'Tavshed', p. 85-101.

Eriksen, Jens-Martin og Frederik Stjernfelt (2008). Adskillelsens politik: Multikulturalisme - ideologi og virkelighed, København: Lindhardt og Ringhof

Furedi, Frank (2005). Politics of Fear: Beyond Left and Right, London: Continuum.

Horkheimer, Max (2007). 'The End of Reason', I Andrew Arato og Eike Gebhardt (red.), The Essential Frankfurt Reader, New York og London: Continuum, p. 26-48.

Lévy, Bernard-Henri (2008). Left in Dark Times: A Stand Against the New Barbarism, New York: Random House.

Lindsey, Brink (2007). The Age of Abundance: How Prosperity Transformed America's Politics and Culture, New York: Collins.

Lukes, Steven (2003). 'Epilogue: The Grand Dichotomy of the Twentieth Century', i Terence Ball og Richard Bellamy (red.), TwentiethCentury Political Thought, Cambridge: Cambridge University Press, p. 602-626

Malik, Kenan (2008). Strange Fruit: Why Both Sides are Wrong in the Race Debate, Oxford: Oneworld

Malik, Kenan (2009). From Fatwa to Jihad: The Rushdie Affair and Its Legacy, London: Atlantic Books.

Markovits, Andrei S. (2005). 'The European and American Left since 1945', Dissent, Vol. 52, Issue 1, p. 5-13.

Sassoon, Donald (2010). One Hundred Years of Socialism, London \& New York: I.B. Tauris. sig til at være korrupte, autoritære og reaktionære, er man i dag heller ikke håndsky for at alliere sig med radikal islamisme, da det er den mest markante vare på den antiimperialistiske hylde, og vel at mærke en, der siden fatwaen mod Rushdie har appelleret til det multikulturelle, politisk korrekte og forskræmte venstrefløjssegment.

Stjernfelt, Frederik og Søren Ulrik Thomsen (2005), Kritik af den negative opbyggelighed, København: Vindrose.

Sørensen, Bo Wagner, Yvonne Mørck og Sofie Danneskiold-Samsøe (2012). 'Tavshed og vold mod kvinder', i Tidsskriftet Antropologi, Nr. 65: 'Tavshed', p. 103-127.

Taverne, Dick (2005). The March of Unreason: Science, Democracy and the New Fundamentalism, Oxford: Oxford University Press.

\section{Noter}

1. For en grundig diskussion af udviklingen af multikulturalisme og forskellige former for multikulturalisme, se Eriksen og Stjernfelt 2008: Del II.

2. Bronner 2004 kommer ind på, at fællesnævneren for adskillige typer venstrefløjskritik er „a basic discomfort with the notion of progress": 17

3. Jf. Sassoon 2010: 390-392, hvor han nævner, at det nye venstres libertære kritik af stat og hierarkiske autoriteter influerede neoliberale trends i 1980/90erne.

4. Stjernfelt og Thomsen 2005: 17-19. Se også Bérubés 2009: 84, hvor han beskriver magt/modmagt logikken, der præger venstrefløjen og som han omtaler som „the countercultural logic“: „the greater the number of people who disagree with you, the more clearly and bravely you must be speaking truth to power". Se også 11-12, 41, 86.

5. Det er interessant at se, at venstrefløjen overtog islamisternes retorik om at muslimers følelser var blevet krænket af Rushdies The Satanic Verses. Den egentlige motivation for Khomeinis fatwa var snarere, at hans forsøg på at udbrede den islamistiske revolution og overtage lederrollen efter Saudi Arabien var gået i stå.

6. Bonnet 2010, kap. 3 diskuterer bl.a. disse temaer ift. former for venstrefløjsnostalgi, der er knyttet til anti- og postkolonialisme. Se også Malik 2008: 183-189.

7. Det er et flittigt brugt argument, hvilket også var fremme i forbindelse med Jyllandspostens „Muhammed tegninger“. Derudover er det en strategi, der blev lanceret af Iran og senere af Organization of Islamic Conference (OIC), der i antiimperialistiske vendinger appellerede til venstreorienterede i Vesten om at støtte de svage mod de stærke. Cohen 2012: 29-32. 